\title{
Characterization of Pyrethroid Resistance Mechanisms in Aedes aegypti from the Florida Keys
}

\author{
Mariah L. Scott, ${ }^{1 \star}$ Lawrence J. Hribar, ${ }^{2}$ Andrea L. Leal, ${ }^{2}$ and Janet C. McAllister ${ }^{1}$ \\ ${ }^{1}$ Arbovirus Diseases Branch, Division of Vector-Borne Diseases, Centers for Disease Control and Prevention, Fort Collins, Colorado; ${ }^{2}$ Florida Keys \\ Mosquito Control District, Key West, Florida
}

\begin{abstract}
The status of insecticide resistance in Aedes aegypti is of concern in areas where Aedes-borne arboviruses like chikungunya, dengue, and Zika occur. In recent years, outbreaks involving these arboviruses have occurred, for which vaccines do not exist; therefore, disease prevention is only through vector control and personal protection. Aedes aegypti are present on every inhabited island within the Florida Keys. The resistance status of $A$ e. aegypti in the Florida Keys was assessed to guide knowledge of the best choice of chemical for use during an outbreak. Mosquito eggs were collected using ovitraps placed on Key West, Stock Island, Vaca Key, Upper Matecumbe Key, Plantation Key, and Key Largo. Bottle bioassays were conducted at the Florida Keys Mosquito Control District using Biomist ${ }^{\circledR} 30+30$ (Clarke Mosquito Control Products, Inc., Roselle, IL). Further bottle testing using malathion and permethrin occurred at the CDC, Fort Collins, CO, in addition to molecular and biochemical assays. Levels of resistance varied between islands with different underlying mechanisms present. Resistance was seen to Biomist ${ }^{\circledR} 30+30$ but not to permethrin, indicating that piperonyl butoxide (PBO) or the inert ingredients may be involved in resistance. No study has been conducted to date examining the role of PBO in resistance. Key Largo was treated the most with adulticides and expressed the highest levels of alpha and beta esterases, oxidases, glutathione-S-transferases, and frequency of the $\mathrm{V} 1016 \mathrm{l}$ knockdown mutation from all sites tested. Knowledge of localized resistance and underlying mechanisms helps in making rational decisions in selection of appropriate and effective insecticides.
\end{abstract}

\section{INTRODUCTION}

Control of mosquitoes is important because of their ability to spread disease, their impact on local economies, and the low tolerance of the public to high numbers of biting mosquitoes. In the absence of vaccines, vector control and/or personal protection remain the mainstays for the prevention of infection with pathogens transmitted by mosquitoes. Organized vector control programs and personal protection strategies rely on the use of insecticides to varying degrees. Vector control programs may incorporate space spraying, outdoor residual spraying, and larviciding as part of their overall strategy. Personal protection strategies may include repellents, insecticide-treated clothing, and the use of screens on doors and windows. In addition to the use of chemicals, sanitation of premises and modification of the environment to inhibit mosquito development may also be undertaken, but is resource intensive and challenging.

During the last 50 years, increased use, overuse, and even misuse of insecticides have led to insecticide resistance both internationally and within the United States. Roman Sawicki ${ }^{1}$ defined insecticide resistance as a genetic change in response to selection by toxicants that may impair control in the field. When the genetic change is due to a small proportion of resistant individuals or low levels of resistance, it may be only perceptible by sensitive bioassays and be insufficient to impair control of the organism in real-world applications. With this definition, resistance can be recognized before a particular compound is no longer effective for operational use. The number of mosquito adulticides offered is limited in the United States. Only two chemical classes of adulticides, organophosphates and pyrethroids, with differing modes of action are available. In the Florida Keys, both classes of adulticides are used. Surveillance for resistance in local populations

\footnotetext{
${ }^{*}$ Address correspondence to Mariah L. Scott, Arbovirus Diseases Branch, Division of Vector-Borne Diseases, Centers for Disease Control and Prevention, 3156 Rampart Rd., Fort Collins, CO 80524. E-mail: gni6@cdc.gov
}

needs to be ongoing as changes in insecticide use can lead to changes in selective pressure for development and maintenance of resistance. Furthermore, knowledge of localized resistance and underlying mechanisms helps in making rational decisions in the selection of appropriate and effective insecticides. $^{2}$

Insecticide resistance has long been a concern in public health programs aimed at preventing disease through the judicious use of insecticides. In the United States, mosquito insecticide resistance was first detected in Aedes nigromaculis (Ludlow), which demonstrated resistance to dichloro-diphenyl-trichloroethane (DDT) in $1950 .^{3}$ The first reported case of resistance in Aedes aegypti (L.) occurred in Puerto Rico in 1960 to DDT. ${ }^{4}$ By 1964, resistance had been reported in Ae. aegypti to benzene hexachloride/cyclodienes, malathion, and DDT in Florida, Surinam, Barbados, Lesser Antilles, and the Virgin Islands. ${ }^{5-8}$ Since then, 558 reports of resistance to 32 insecticides from seven different chemical classes have been reported for Ae. aegypti from 50 countries to the Arthropod Pesticide Resistance Database maintained by Michigan State University (http://www.pesticideresistance.org/).

The status of insecticide resistance in Ae. aegypti is of particular concern in areas where Aedes-borne arboviruses like chikungunya, dengue, and Zika occur. In recent years, multiple outbreaks involving these arboviruses have occurred. Dengue cases surged in the Americas from 2000 to 2010, resulting in the greatest record of cases ever being reported in a decade. ${ }^{9}$ From 2010 to 2015, 112 outbreaks of dengue have occurred worldwide. ${ }^{10}$ For chikungunya, nearly 1 million cases had been reported in the Americas by the end of $2015 .{ }^{11}$ Zika virus spread throughout the Caribbean and Central and South America in 2015-2016. By the middle of 2016, Zika virus had spread locally in more than 30 countries. ${ }^{12}$ Outbreaks in the continental United States of dengue and Zika viruses occurred in Key West, FL, and Miami-Dade County, FL, respectively. ${ }^{10}$ Data documenting levels of insecticide resistance in many dengue-endemic countries are lacking; however, in countries with active monitoring programs, results indicate that insecticide resistance is reducing the ability to control dengue vectors. ${ }^{13}$ 
We undertook this study to identify the insecticide resistance mechanisms present in populations of Ae. aegypti throughout the Florida Keys to assist the Florida Keys Mosquito Control District in identifying issues that might require changes in current control practices.

\section{METHODS AND MATERIALS}

Mosquito eggs were collected using nonlethal and lethal ovitraps. Nonlethal ovitraps were produced by the Florida Keys Mosquito Control District and included a black plastic cup lined with seed germination paper. SpringStar ${ }^{\circledR}$ Inc. (Saint Louis, MO) provided the lethal ovitraps for testing which were covered under an experimental use permit granted by the state of Florida (Environmental Protection Agency Headquarters Office of Pesticide Programs-2010-0576; Federal Register Log-8840-8). The Trap-N-Kill ${ }^{\mathrm{TM}}$ (SpringStar ${ }^{\circledR}$ Inc., Saint Louis, $\mathrm{MO})$ was augmented with ovitrap strips impregnated with $80 \mathrm{mg}$ of bifenthrin and lined with red felt strips for egg collection. Nonlethal ovitraps were placed on Key West, Stock Island, Vaca Key, Upper Matecumbe Keys Plantation Key, and Key Largo (Figure 1) in 2010. Additional eggs were collected using nonlethal ovitraps in 2012 from Upper Matecumbe to augment results from molecular assays. Lethal ovitraps were deployed only on Key West because of the experimental use permit. All ovitraps were placed in the field and allowed to sit for 3 days. Egg papers were removed and sent to the CDC, Division of Vector-Borne Diseases, Arboviral Disease Branch, in Fort Collins, $\mathrm{CO}$, where eggs were hatched by placement in a vacuum chamber for 1 hour. Larvae were kept in $30.5 \times$ $15.2 \times 5.1 \mathrm{~cm}$ white plastic pans (BioQuip, Rancho Dominguez, CA) with Plexiglas ${ }^{\circledR}$ (BioQuip, Rancho Dominguez, CA) sheets for lids. Larval diet consisted of ground Tetramin ${ }^{\circledR}$ tropical flakes (Tetra Holding, Blacksburg, VA) and liver powder (MP Biomedicals, Solon, $\mathrm{OH}$ ) fed to larvae every 3 days. Pupae were collected daily and placed in water-filled cups inside $30.5 \times 30.5 \times 30.5 \mathrm{~cm}$ cages (BioQuip). Larvae, pupae, and adults were kept in environmental chambers at $37^{\circ} \mathrm{C}$ 85-90\% relative humidity and a 14:10 light dark cycle. Adults were fed $10 \%$ sugar until they were $5-7$ days old. They were either used directly for bioassays or frozen and stored at $-80^{\circ} \mathrm{C}$ for later use in enzymatic and molecular assays.

Testing conducted at the Florida Keys Mosquito Control District used larvae collected from Vaca Key and Key West. Larvae were reared in $1 \mathrm{~L}$ jars at ambient temperature and lighting conditions in the laboratory and fed liver powder daily. Adults were fed $10 \%$ sucrose solution until they were $3-5$ days old.

Preliminary bioassays were conducted in the laboratory of the Florida Keys Mosquito Control District using the Public Health Entomology Research and Education Center (PHEREC) bottle bioassay protocol for Biomist ${ }^{\circledR} 30+30 .{ }^{14}$ This assay tests formulated products, not technical-grade active ingredients as in the CDC bottle bioassay. Biomist $30+30$ is a formulated product composed of 30\% permethrin (35:65 cis:trans), 30\% piperonyl butoxide (PBO), and $40 \%$ other ingredients. According to the label, $3.79 \mathrm{~L}$ of Biomist $30+30$ contains $1.13 \mathrm{~kg}$ of permethrin. A stock solution was made by diluting $1 \mathrm{~mL}$ of Biomist $30+30$ in $100 \mathrm{~mL}$ of acetone which contains $2.99 \mathrm{mg} / \mathrm{mL}$ of permethrin. From this stock solution, $1.44 \mathrm{~mL}$ was diluted in $100 \mathrm{~mL}$, resulting in a test solution with a concentration of $43 \mu \mathrm{g} / \mathrm{mL}$ of permethrin. The test solution for Biomist $30+30$ used in the assay only takes into account the amount of permethrin in the product and not the other components of the formulation. The interior surface of a 250-mL Wheaton bottle was coated with $1 \mathrm{~mL}$ of the test solution resulting in a final concentration of $43 \mu \mathrm{g} / \mathrm{mL}$ of permethrin per bottle. Three bottles were treated with the test solution, and one bottle was treated with acetone only to serve as the control. After permitting the acetone to evaporate, between 10 and $20 \mathrm{Ae}$. aegypti of both sexes were placed into bottles and mortality recorded every 15 minutes. For comparative purposes, eggs from the known susceptible Ae. aegypti Orlando strain and resistant Ae. aegypti Puerto Rico strain were obtained from the U.S. Department of Agriculture, the Center for Medical, Agricultural, and Veterinary Entomology, in Gainesville, FL. Eggs were reared in the same manner as the larvae from Florida Keys Mosquito Control District, and adults were subjected to PHEREC bottle bioassays.

CDC bottle bioassays were conducted in Fort Collins using the protocol of Brogdon and McAllister ${ }^{15}$ using technicalgrade active ingredients. In brief, $15 \mu$ g permethrin (25:75 cis: trans), $10 \mu \mathrm{g}$ bifenthrin, or $50 \mu \mathrm{g}$ malathion, dissolved in

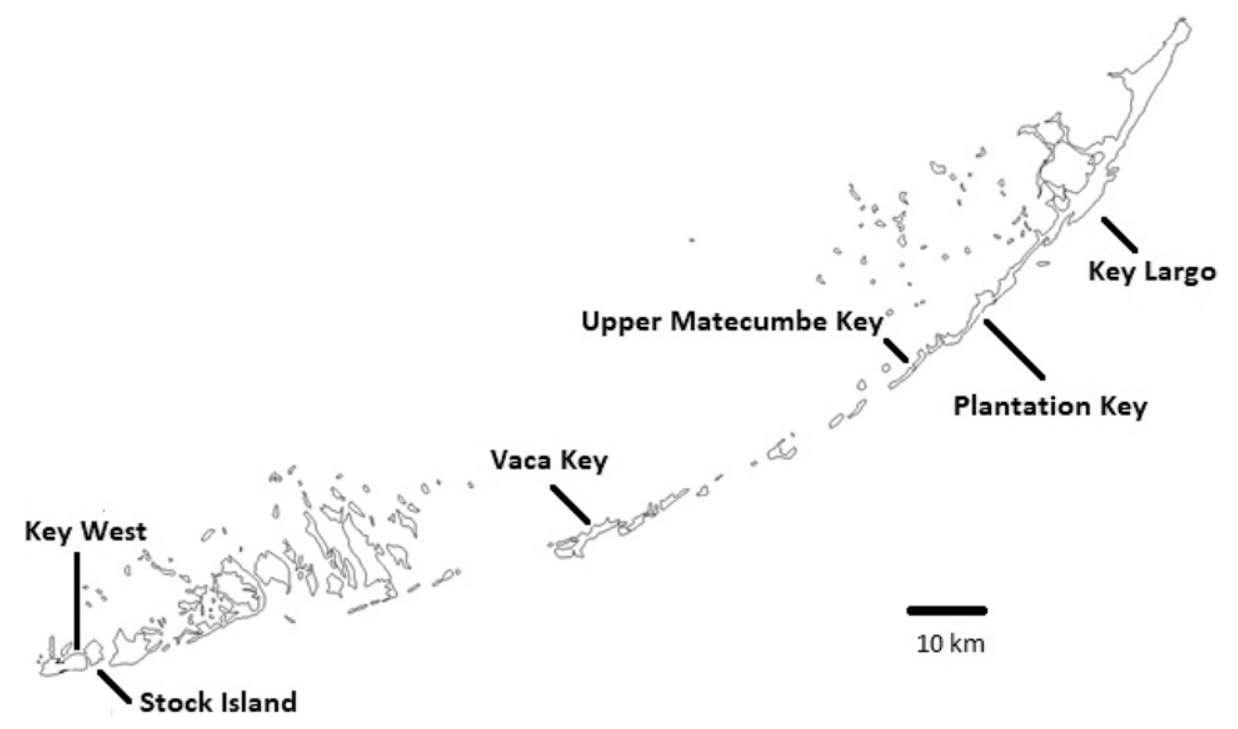

FIGURE 1. Localities sampled for Aedes aegypti in Monroe County, FL. 
acetone, was applied to 250-mL glass bottles. Enzyme inhibitors were used to determine the presence of metabolic resistance mechanisms. Piperonyl butoxide inhibits oxidase activity, S.S.S.-tributylphosphorothioate (DEF) inhibits esterase activity, and diethyl maleate (DEM) inhibits glutathione transferase activity. Bottles were treated with $400 \mu \mathrm{g}$ PBO, $125 \mu \mathrm{g}$ DEF, or $80 \mu \mathrm{g}$ DEM in conjunction with $10 \mu \mathrm{g}$ bifenthrin. All insecticides were purchased as technical-grade material from ChemService (Westchester, PA). Five bottles were used for each assay, four bottles were treated for each compound, and one untreated bottle containing only acetone was used as the control. After bottles were prepared, a combination of 25-35 male and female mosquitoes was introduced into each bottle. Mortality was considered to have occurred if the mosquito could not stand or fly. Observations of mortality were recorded at $T=0,5,10$, and 15 and every 15 minutes thereafter until all mosquitoes were dead or 2 hours had elapsed.

Assays to measure increased levels of detoxifying enzymes, protein, and the presence of the altered target site for organophosphates were conducted according to published protocols. ${ }^{16-21}$ Detoxifying enzymes measured were alpha $(\alpha)$ and beta $(\beta)$ esterases, oxidases, and glutathione-Stransferase (GST). Individual mosquitoes were ground with a pestle in $2 \mathrm{~mL}$ microtubes containing $100 \mu \mathrm{L}$ of potassium phosphate buffer $\left(12.5 \mathrm{mmol} / \mathrm{L} \mathrm{K}_{2} \mathrm{HPO}_{4}\right.$ and $37.9 \mathrm{mmol} / \mathrm{L}$ $\mathrm{KH}_{2} \mathrm{PO}_{4}$ ) adjusted to $\mathrm{pH}$ 7.2. The homogenate was then diluted with an additional $1,900 \mu \mathrm{L}$ of buffer. All assays were run in triplicate on each mosquito. Unless otherwise noted, all chemicals were purchased from Sigma-Aldrich Chemical Co. (St. Louis, MO).

Oxidases were indirectly measured using a heme-peroxidase assay using the substrate 3,3',5,5'-tetra-methybenzidine (TMBZ). A working solution of TMBZ was prepared by dissolving $50 \mathrm{mg}$ of TMBZ in $25 \mathrm{~mL}$ absolute methanol and adding $75 \mathrm{~mL}$ of $0.25 \mathrm{M}$ sodium acetate buffer $(\mathrm{pH} 5.0 ; \mathrm{pH}$ adjusted with acetic acid). The TMBZ substrate $(200 \mu \mathrm{L})$ was added to $100 \mu \mathrm{L}$ of mosquito homogenate, followed by $25 \mu \mathrm{L}$ of $3 \%$ hydrogen peroxide. Absorbance values of plates were read at $\lambda=620 \mathrm{~nm}$ after a 10 -minute incubation period using a SpectraMax M3 plate reader (Molecular Devices, Sunnyvale, $C A$ ).

For $\alpha$ and $\beta$ nonspecific esterases, $100 \mu \mathrm{L}$ of a $3-\mathrm{mmol} / \mathrm{L}$ solution of $\alpha$ - or $\beta$-napthyl acetate (56 mg $\alpha$ - or $\beta$-napthyl acetate dissolved in $20 \mathrm{~mL}$ of acetone then diluted with $80 \mathrm{~mL}$ of $\mathrm{pH} 7.2$ potassium phosphate buffer) was added to each well. Following a 20-minute incubation period, $100 \mu \mathrm{L}$ of 0-dianisidine (100 mg 0-dianisidine in $100 \mathrm{~mL}$ water) was added to each well. After 4 minutes, the absorbance value for each well was determined at $\lambda=540 \mathrm{~nm}$.

Glutathione-S-transferase was measured using 1-chloro2,4-dinitrobenzene (CDNB) (20 mg CDNB dissolved in $20 \mathrm{~mL}$ acetone and $90 \mathrm{~mL} \mathrm{KPO}_{4}$ buffer added) and reduced glutathione (61 mg reduced glutathione in $100 \mathrm{~mL} \mathrm{KPO}_{4}$ buffer). In brief, $100 \mu \mathrm{L}$ of the reduced glutathione was added to $100 \mu \mathrm{L}$ of the mosquito sample, followed by $100 \mu \mathrm{L}$ of CDNB. Absorbances were read at $T=0$ and 5 minutes with $340 \mathrm{~nm}$ as the wavelength.

A competitive assay that measures insensitivity of acetylcholineesterase was used to detect the presence of the altered target site mechanism that confers organophosphate and carbamate resistance. This competitive assay incorporated propoxur (ChemService) with the substrate acetylthiocholine iodide (ATCH) (75 mg ATCH, 21 mg propoxur, $10 \mathrm{~mL}$ acetone, and $90 \mathrm{~mL} \mathrm{KPO}_{4}$ buffer). One hundred microliters of the substrate was added to $100 \mu \mathrm{L}$ of the mosquito sample, followed by $100 \mu \mathrm{L}$ of $5,5^{\prime}$ dithio-bis-2-nitrobenzoic acid (DTNB) (13 mg DTNB in $100 \mathrm{~mL} \mathrm{KPO}_{4}$ buffer). Absorbances were read at $T=0$ minutes and at $T=24$ hours with a wavelength of $414 \mathrm{~nm}$.

The protein assay was performed using $20 \mu \mathrm{L}$ of mosquito homogenate to which $80 \mu \mathrm{L}$ of $\mathrm{KPO}_{4}$ buffer was added. The assay used is based on the Bradford method (1976) of protein quantification in which $200 \mu \mathrm{L}$ of Bio-Rad Protein Assay Dye Reagent Concentrate (Bio-Rad Laboratories, Hercules, CA) was added, and the absorbance was read at $\lambda=620 \mathrm{~nm}^{16,22}$ A standard curve using bovine serum albumin was calculated to quantitate the total protein present in each mosquito. The preferred gender to test for insecticide resistance is females as they are the ones to transmit pathogens; however, because of the low numbers of individuals available for testing, both females and males were used. The protein assay was used to estimate the size of each individual and used to correct values obtained from the other microplate assays. Variations in mosquito size influence enzyme levels, unless the enzyme is being over or under expressed. Differences in assay values by location of mosquito collection were compared using a oneway analysis of variance. If normality failed using this method, then a Kruskal-Wallis one-way analysis of variance on ranks was performed. When differences were detected with this test, a pairwise multiple comparison procedure was performed using Dunn's method. Dunn's method was not capable of comparing several locations. These locations were compared using a $t$-test. A Mann-Whitney rank-sum test was used if normality failed. The statistical package used was SigmaPlot (SYSTAT Software Inc., Palo Alto, CA).

Molecular assays to look for mutations in the para sodium channel gene, domain II associated with resistance to pyrethroids were used on Ae. aegypti adults that were stored in the $-80^{\circ} \mathrm{C}$ freezer. The melting curve assay was used to detect the lle 1016, Gly 1016, Val 1011, and Met 1011 mutations in Ae. aegypti. Primers and protocols were those described previously. ${ }^{23,24}$ Mosquito genomic DNA was extracted using DNAzol (Molecular Research Center Inc., Cincinnati OH). Individual mosquitoes were homogenized in $200 \mu \mathrm{L}$ of DNAzol using a Kontes pellet pestle cordless motor with disposable pestles (Fisher Scientific, Waltham, MA). The homogenate was incubated at room temperature for 5 minutes, and then centrifuged for 1 minute at 10,000 rpm to remove insoluble tissue. The resulting viscous supernatant was transferred to a new 1.5-mL microtube. The DNA was precipitated from the homogenate by adding $100 \mu \mathrm{L}$ of $100 \%$ ethanol. The samples were mixed by inversion to ensure a homogenous solution and incubated at room temperature for 3 minutes. The samples were centrifuged for 2 minutes at 14,000 rpm or until a visible pellet could be seen. The DNA precipitate was washed twice with $1 \mathrm{~mL}$ of $75 \%$ ethanol, allowed to air-dry for $5-15$ seconds, and then resuspended in $50 \mu \mathrm{L}$ of $\mathrm{H}_{2} \mathrm{O}$.

Genotypes were determined in a single-tube PCR using two different "allele-specific" primers and the reverse primer (Table 1). PCR was performed in a $25-\mu \mathrm{L}$ volume in low-profile 96-well unskirted white PCR plates (Bio-Rad Laboratories). Each reaction contained $12.5 \mu \mathrm{L}$ of $2 \times \mathrm{IQ}^{\mathrm{TM}} \mathrm{SYBR}^{\circledR}$ Green Supermix (Bio-Rad Laboratories, Hercules, CA) (final concentrations $=50 \mathrm{mM} \mathrm{KCl}, 20 \mathrm{mM}$ Tris- $\mathrm{HCl}, \mathrm{pH} 8.4,0.2 \mathrm{mM}$ of each deoxynucleoside triphosphate, 0.625 units iTaq $^{\circledR}$ 
TABLE 1

Sequences of oligonucleotides used in this study for allele-specific PCR

\begin{tabular}{|c|c|c|}
\hline Primers for allele-specific PCR & Sequence $\left(5^{\prime}-3^{\prime}\right)$ & Product size (bp) \\
\hline \multicolumn{3}{|l|}{ Val 1011} \\
\hline Val1011f & ATTGTATGCTTGTGGGTGACG & - \\
\hline Iso1011r & GCGGGCTACTTACTACTAGATTTCCAAT & 84 \\
\hline Val1011r & GCGGGCAGGGCGGCGGGGGCGGGGCCTACTTACTACTAGATTTCCGAC & 104 \\
\hline \multicolumn{3}{|l|}{ Met 1011} \\
\hline Met1011f & GTCCTGTATTCCGTTCTIIT & - \\
\hline Iso1011r & GCGGGCAGGGCGGCGGGGGCGGGGCCTACTTACTACTAGATTTGCC & 62 \\
\hline Met1011r & GCGGGCTACTTACTACTAGATTTACT & 82 \\
\hline \multicolumn{3}{|l|}{ Ile 1016} \\
\hline Val1016f & GCGGGCAGGGCGGCGGGGGCGGGGCCACAAATTGTTCCCACCCGCACCGG & 102 \\
\hline lle1016f & GCGGGCACAAATTGTTTCCCACCCGCACTGA & 62 \\
\hline lle1016r & GGATGAACCSAAATTGGACAAAAGC & - \\
\hline \multicolumn{3}{|l|}{ Gly 1016} \\
\hline Gly1016f & ACCGACAAATTGTTTCCC & - \\
\hline Val1016r & GCGGGCAGCAAGGCTAAGAAAAGGTTAATTA & 60 \\
\hline Gly1016r & GCGGGCAGGGCGGCGGGGGCGGGGCCAGCAAGGCTAAGAAAAGGTTAACTC & 80 \\
\hline
\end{tabular}

DNApolymerase (Bio-Rad Laboratories, Hercules, CA), $3 \mathrm{mM}$ $\mathrm{MgCl}_{2}, 1 \times$ SYBR Green I, and $10 \mathrm{nM}$ fluorescein), $25 \mathrm{pM}$ of each primer, $\sim 40 \mathrm{ng}$ of template DNA, and sterile filtered $\mathrm{dd}_{2} \mathrm{O}$ water added to make a final $25-\mu \mathrm{L}$ volume. The melting curve PCR reaction was performed on an Eppendorf Mastercycler ep realplex ${ }^{4} \mathrm{~S}$ (Eppendorf, Enfield, CT). The thermal cycling conditions were modified from the experimental procedure to the following: 1) $95^{\circ} \mathrm{C}$ for 4 minutes (first denature), 2) $95^{\circ} \mathrm{C}$ for 10 seconds (denature in cycle), 3) $60^{\circ} \mathrm{C}$ for $10 \mathrm{sec}-$ onds (anneal), 4) $72^{\circ} \mathrm{C}$ for 30 seconds (extension), 5) cycle to step (2) 39 times, 6) $95^{\circ} \mathrm{C}$ for 10 seconds, and 7) ramp from $65^{\circ} \mathrm{C}$ to $95^{\circ} \mathrm{C}$ at a rate of $0.2^{\circ} \mathrm{C} / 10$ seconds (melting curve).

Each of the four single nucleotide polymorphism loci had three different genotypes. The Iso 1011/Iso 1011 homozygote has a single peak at $80^{\circ} \mathrm{C}$, the $\mathrm{Val} 1011 / \mathrm{lso} 1011$ heterozygote has two peaks at $80^{\circ} \mathrm{C}$ and $85^{\circ} \mathrm{C}$, and the Val $1011 / \mathrm{Nal} 1011$ homozygote has a single peak at $85^{\circ} \mathrm{C}$. A single peak at $72^{\circ} \mathrm{C}$ indicates a Met 1011/Met 1011 homozygote, whereas two peaks at $77^{\circ} \mathrm{C}$ and $82^{\circ} \mathrm{C}$ indicate a Met $1011 /$ lso 1011 heterozygote. An lle 1016/lle 1016 homozygote has a single peak at $80^{\circ} \mathrm{C}$, the lle $1016 / \mathrm{Val} 1016$ heterozygote has two peaks at $80^{\circ} \mathrm{C}$ and $88^{\circ} \mathrm{C}$, and the $\mathrm{Val} 1016 / \mathrm{Val} 1016$ has a single peak at $88^{\circ} \mathrm{C}$. Two peaks at $79^{\circ} \mathrm{C}$ and $84^{\circ} \mathrm{C}$ indicated a Gly $1016 / \mathrm{Val}$ 1016 heterozygote, whereas a single peak at $79^{\circ} \mathrm{C}$ indicated a Val 1016/Val 1016 homozygote. Frequencies of the Val 1011, Met 1011, lle 1016, and Gly 1016 alleles were estimated along with $95 \%$ Cls.

\section{RESULTS}

Using the updated $\mathrm{WHO}^{25}$ guidelines, populations were classified as resistant or susceptible: $98-100 \%$ mortality indicates susceptibility, 90-97\% mortality suggests resistance may be developing, and mortality less than $90 \%$ indicates resistance. In the PHEREC bottle bioassays conducted at Florida Keys Mosquito Control District, phenotypic resistance was detected to Biomist 30+30 in mosquitoes collected from Vaca Key and Key West compared with the susceptible and resistant strains from the United States Department of Agriculture (Figure 2). Using the susceptible Ae. aegypti Orlando strain as a reference point, the diagnostic time in which $100 \%$ mortality should be observed is 30 minutes. For both Vaca Key and Key West, 100\% of mosquitoes tested were able to survive past the diagnostic time, indicating a very high level of resistance. Survivors were still seen at the conclusion of the test from both sites signifying that resistance to Biomist $30+30$ is fixed in these populations. CDC bottle bioassay testing showed no phenotypic resistance to malathion or permethrin in mosquitoes collected from Key West as $100 \%$ mortality was seen at the diagnostic time (Figure 3 ). The diagnostic time of 30 minutes for malathion and permethrin was determined using the susceptible Ae. aegypti (Rexville, Puerto Rico) colony. Resistance is developing to bifenthrin in

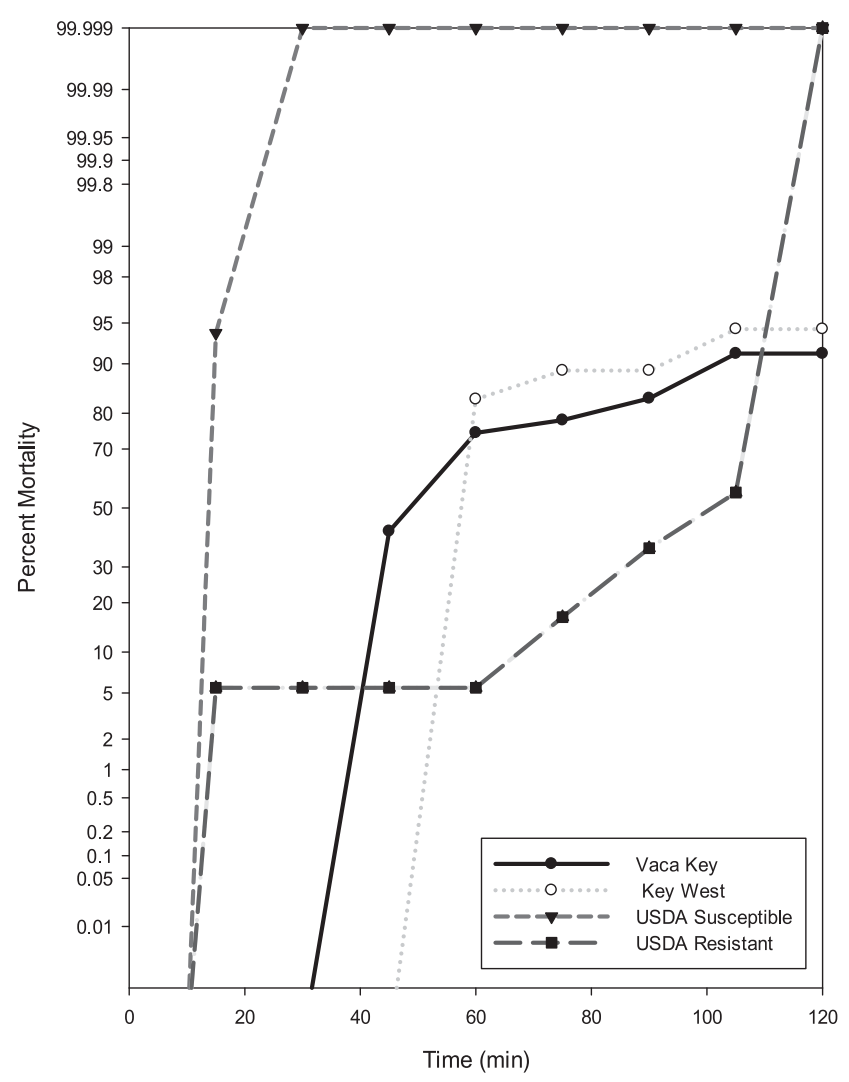

FIGURE 2. Public Health Entomology Research and Education Center bottle bioassay mortality curves for Monroe County, FL: Aedes aegypti challenged with Biomist $30+30$, compared with known susceptible and resistant strains from the USDA. 


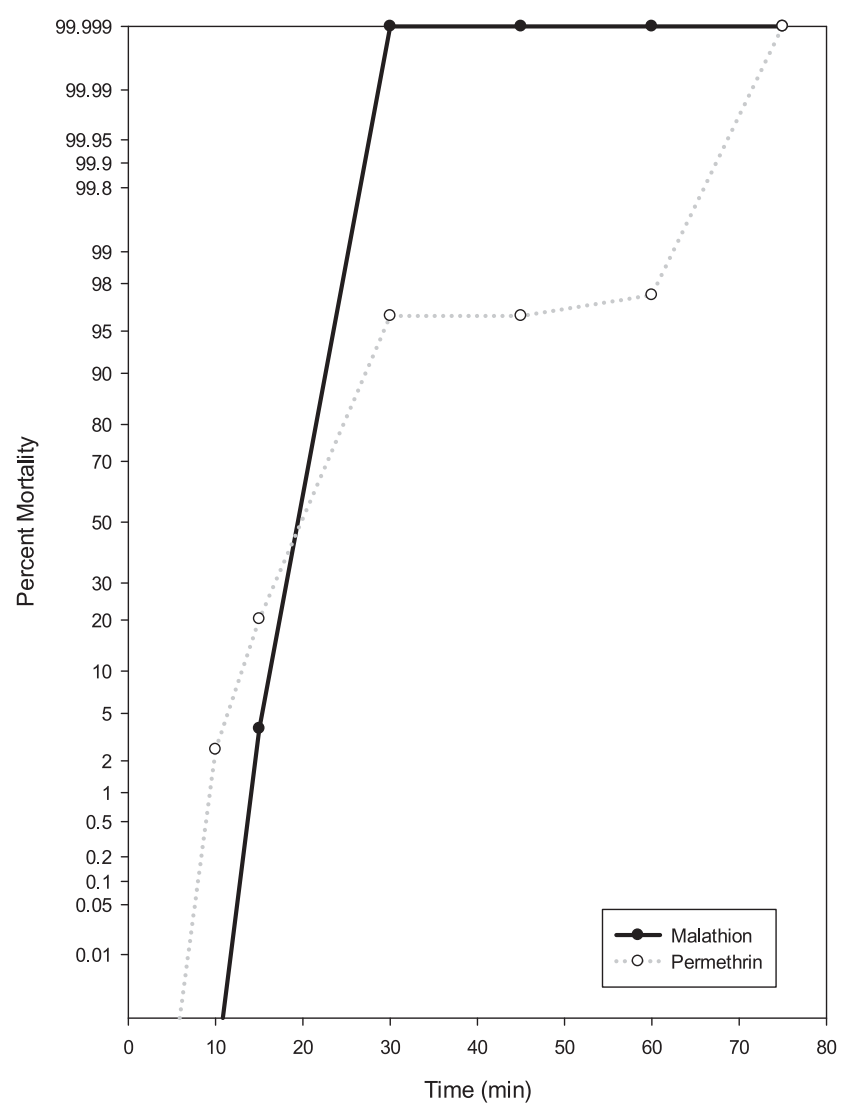

Figure 3. Phenotypic expression of insecticide resistance in Aedes aegypti collected from Key West, FL, using the CDC bottle bioassay.

mosquitoes collected from lethal ovitraps in Key West, with only $90.2 \%$ mortality at the diagnostic time of 75 minutes. Enzyme inhibitors were run in conjunction with bifenthrin to determine the presence of metabolic resistance mechanisms. For DEM, PBO, and DEF, $100 \%$ mortality was seen at 15, 75, and 60 minutes, respectively (Figure 4). Resistance to bifenthrin was abolished using DEM and DEF, which suggests that glutathione transferase and esterase are playing a role in resistance.

Enzyme assays were conducted on Ae. aegypti mosquitoes from Upper Matecumbe Key, Stock Island, Key Largo, Key West, and Vaca Key. Survivors from the lethal ovitraps deployed in Key West were also tested. Females (median $119.76 \mu \mathrm{g}$ protein/mL) and males (median $85.44 \mu \mathrm{g}$ protein/ $\mathrm{mL}$ ) were significantly different in size, with males being smaller. Males and females were compared separately. Females were available from Key Largo $(N=2)$, Key West $(N=55)$, and as survivors of lethal ovitraps $(N=30)$. Female mosquitoes from Key Largo were omitted from statistical analysis because of low sample size. Key Largo and Key West are 140 km apart, representing the populations that have the greatest distance between them. Males were available from Key Largo $(N=20)$, Vaca Key $(N=9)$, Stock Island $(N=21)$, Key West $(N=25)$, and Upper Matecumbe Key $(N=30)$.

Alpha esterase levels (Figure 5) were normally distributed, and there was no statistical difference detected between females from Key West (median $0.233 \mu \mathrm{g} \mathrm{\alpha} / \mu \mathrm{g}$ protein) and lethal ovitrap survivors in Key West (median $0.238 \mu \mathrm{g} \mathrm{\alpha} / \mu \mathrm{g}$ protein), but both sites were significantly different from the colony (median $0.283 \mu \mathrm{g} \mathrm{\alpha} / \mu \mathrm{g}$ protein). Beta esterase levels were not

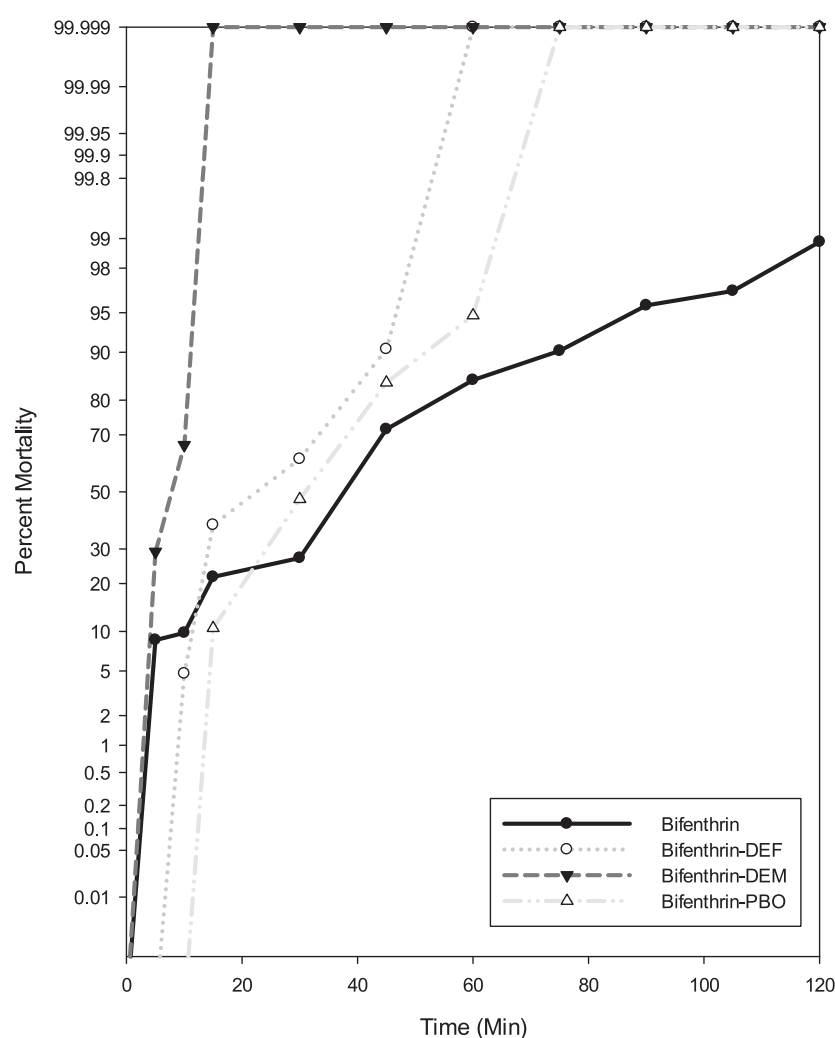

Figure 4. Phenotypic expression of insecticide resistance in Aedes aegypti collected from lethal ovitraps in Key West, FL, using the CDC bottle bioassay.

normally distributed. Lethal ovitrap survivors (median $0.430 \mu \mathrm{g}$ $\beta / \mu \mathrm{g}$ protein) had higher $\beta$ esterase levels than the general population from Key West (median $0.228 \mu \mathrm{g} \beta / \mu \mathrm{g}$ protein) and the colony (median $0.330 \mu \mathrm{g} \beta / \mu \mathrm{g}$ protein). Oxidase levels were also not normally distributed and were higher in the general population from Key West (median $0.00209 \mu \mathrm{g}$ oxidase/ $\mu \mathrm{g}$ protein) than in the lethal ovitrap survivors (median $0.00157 \mu \mathrm{g}$ oxidase $/ \mu \mathrm{g}$ protein) and the colony (median $0.00170 \mu \mathrm{g}$ oxidase/ $\mu \mathrm{g}$ protein). Glutathione-S-transferase levels were not significantly different between Key West in general (median $0.0783 \mu \mathrm{g} \mathrm{GST} / \mu \mathrm{g}$ protein) and the ovitrap survivors (median $0.0719 \mu \mathrm{g}$ GST/ $\mu$ g protein), but both were significantly higher than the colony (median $0.0178 \mu \mathrm{g} \mathrm{GST} / \mu \mathrm{g}$ protein). Using absorbance ranges described in Scott and McAllister ${ }^{26}$ for the acetylcholinesterase (ACE-1) mutation, the frequency of the mutation in Key West and ovitrap individuals was 0.036 (95\% Cl: 0.096$)$ and 0.35 (95\% Cl: 0.125$)$, respectively. This target site mutation is associated with organophosphate/carbamate resistance.

There were significant differences between $\alpha$ and $\beta$ esterases among males (Figure 6). For $\alpha$ esterase, Upper Matecumbe Key (median $0.452 \mu \mathrm{g} \alpha / \mu \mathrm{g}$ protein), Stock Island (median $0.356 \mu \mathrm{g} \mathrm{\alpha / \mu g}$ protein), and Key Largo (median 0.838 $\mu \mathrm{g} \alpha / \mu \mathrm{g}$ protein) had significantly higher levels than the susceptible colony (median $0.258 \mu \mathrm{g} \alpha / \mu \mathrm{g}$ protein), Key West (median $0.237 \mu \mathrm{g} \alpha / \mu \mathrm{g}$ protein), and Vaca Key (median 0.258 $\mu \mathrm{g} \alpha / \mu \mathrm{g}$ protein). Alpha esterase levels between Key West, Vaca Key, and the colony were not significantly different. Significantly higher levels of $\beta$ esterase were detected in Upper Matecumbe Key (median $0.518 \mu \mathrm{g} \beta / \mu \mathrm{g}$ protein), Key West 
Alpha Esterase

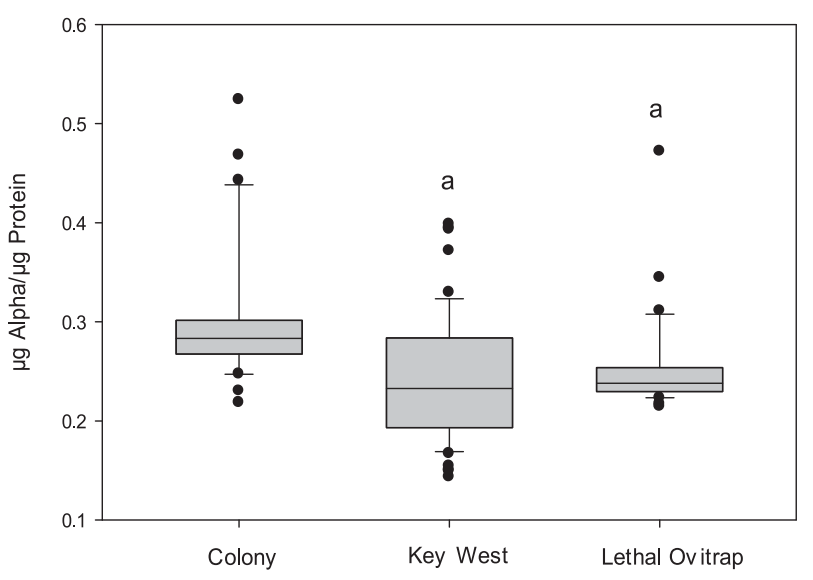

Oxidase

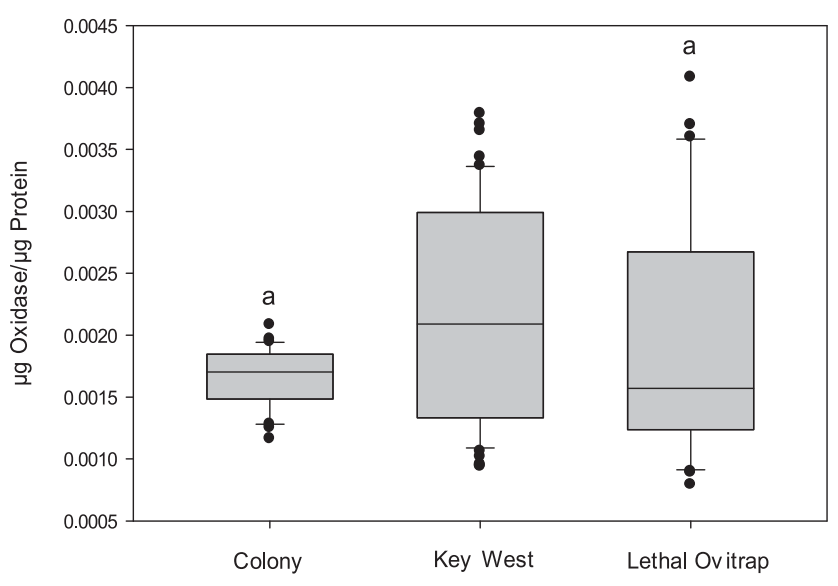

Beta Esterase
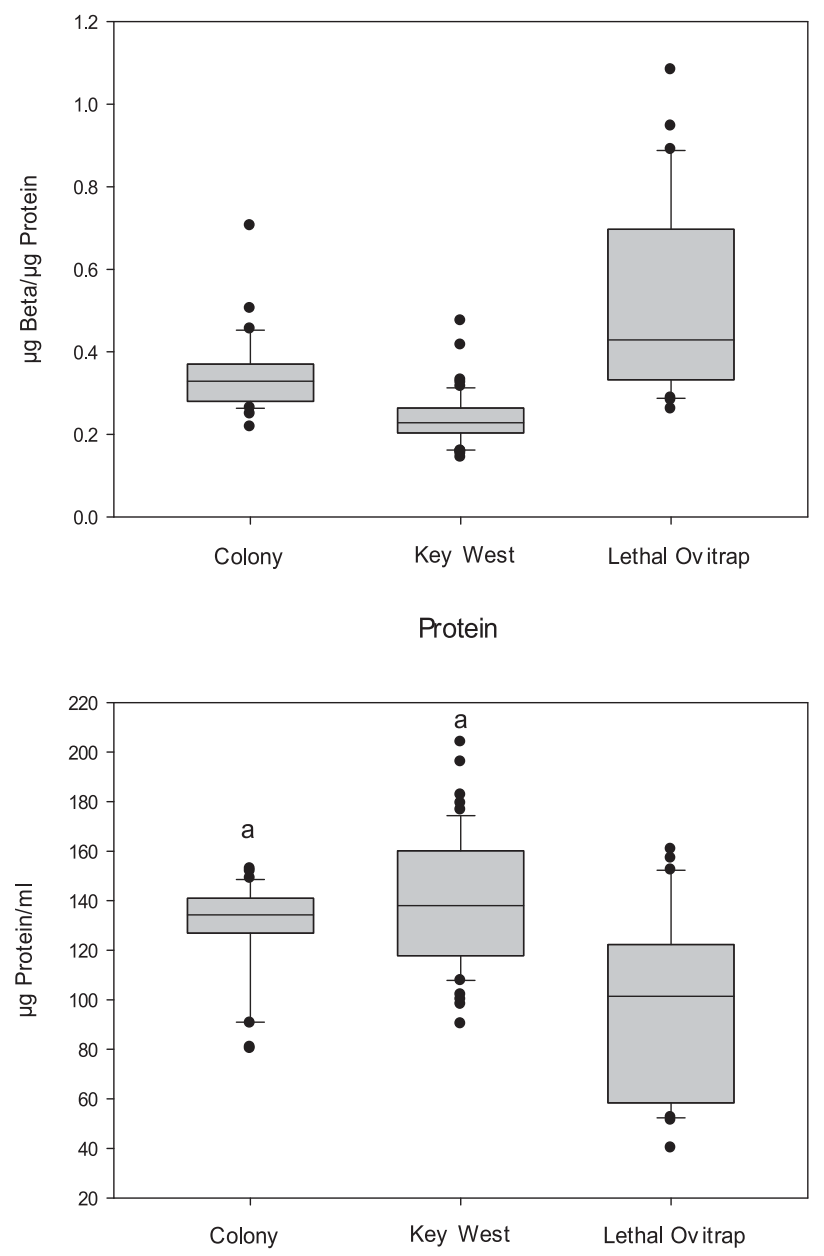

GST

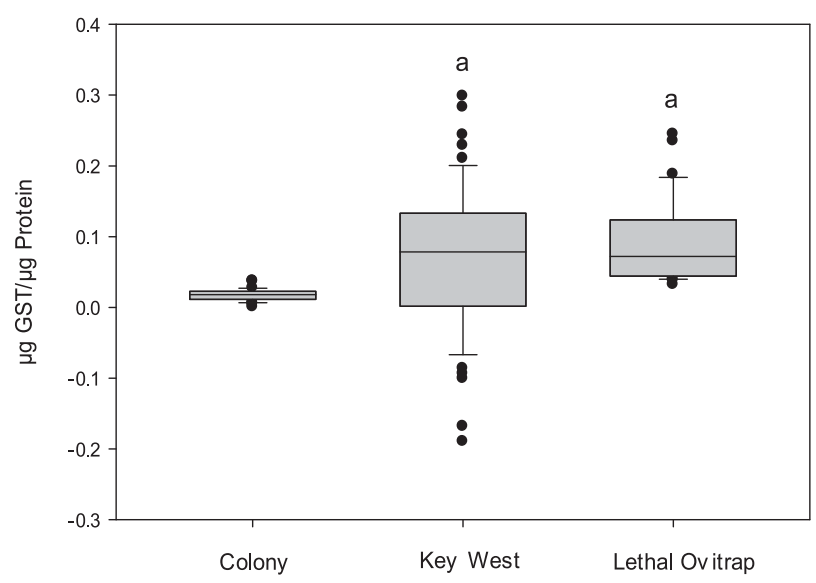

FIGURE 5. Box plots characterizing the 25th, 50th, and 75th percentiles of enzyme levels measured in female Aedes aegypti collected from lethal and nonlethal ovitraps in Key West, FL, compared with susceptible colony. Outliers lie outside the 10th and 90th percentiles as symbols. Identical letters denote no significant difference at $P<0.05$.

(median $0.469 \mu \mathrm{g} \beta / \mu \mathrm{g}$ protein), Stock Island $(0.356 \mu \mathrm{g} \beta / \mu \mathrm{g}$ protein), and Key Largo (median $0.370 \mu \mathrm{g} \beta / \mu \mathrm{g}$ protein) when compared with the colony (median $0.297 \mu \mathrm{g} \beta / \mu \mathrm{g}$ protein), except again for Vaca Key (median $0.277 \mu \mathrm{g} \beta / \mu \mathrm{g}$ protein). For oxidase, mosquitoes from Upper Matecumbe Key (median $0.00135 \mu \mathrm{g}$ oxidase/ $\mu \mathrm{g}$ protein), Key West (median $0.00141 \mu \mathrm{g}$ oxidase/ $\mu$ g protein), Stock Island (median $0.00136 \mu \mathrm{g}$ oxidase/ $\mu \mathrm{g}$ protein), and Key Largo (median $0.00135 \mu \mathrm{g}$ oxidase/ $\mu \mathrm{g}$ 
Alpha Esterase

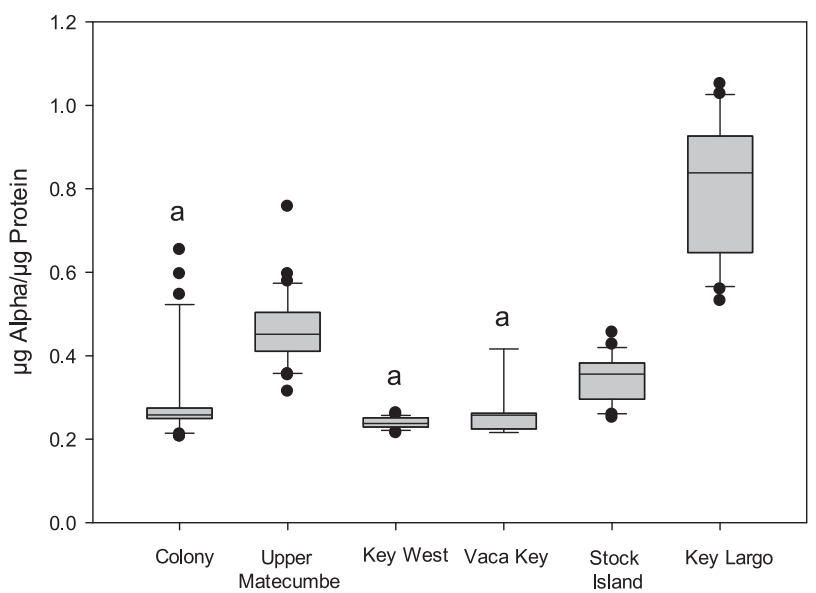

Oxidase

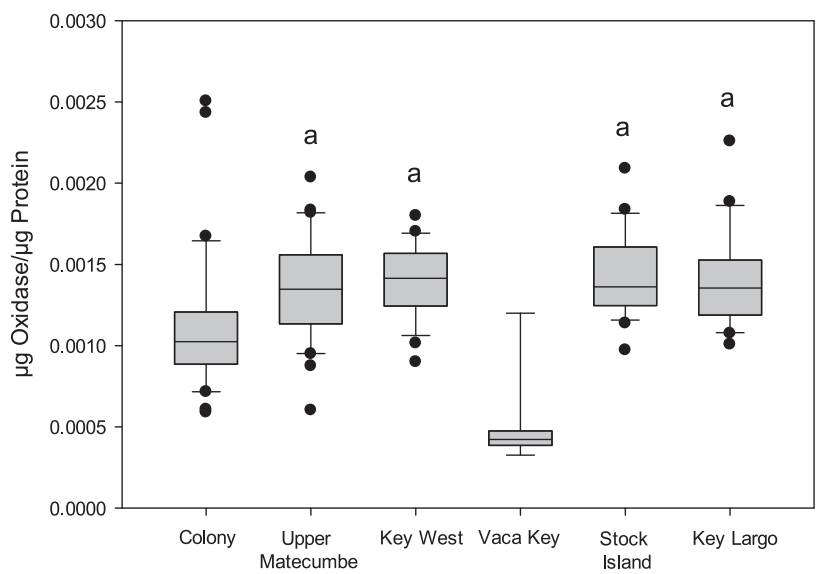

Beta Esterase

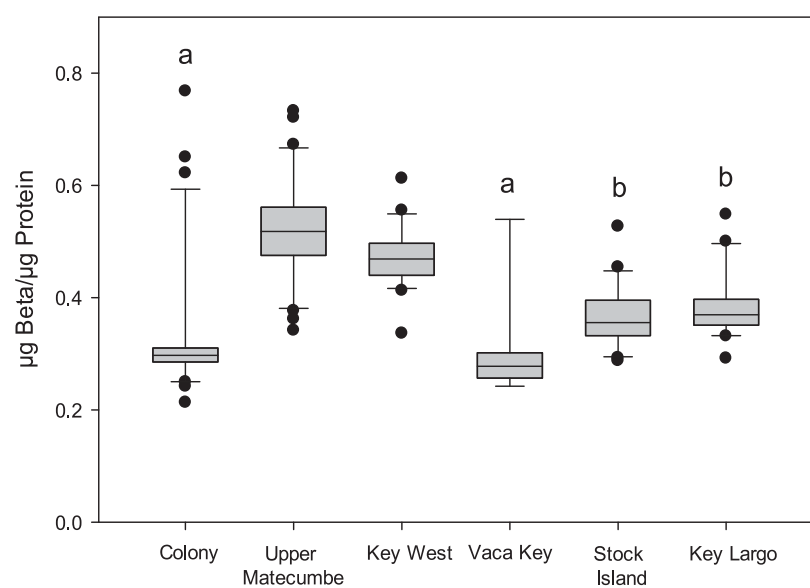

Protein

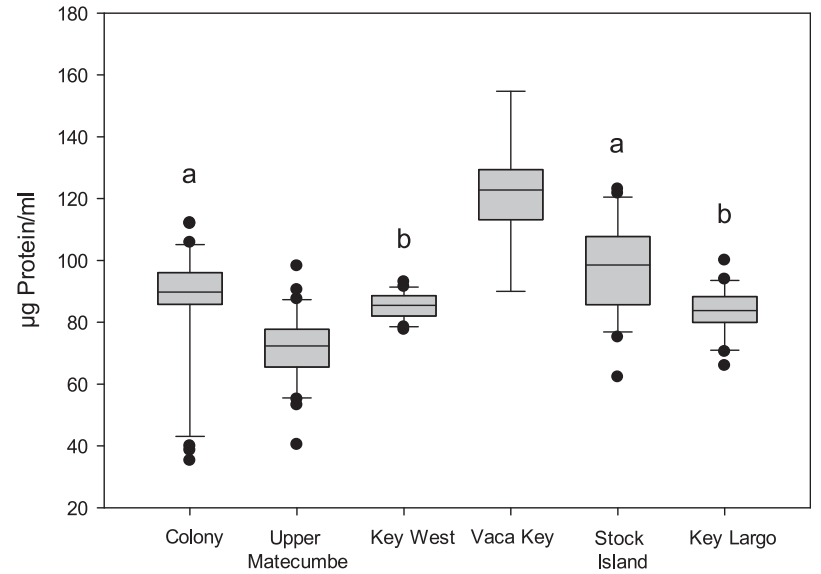

GST

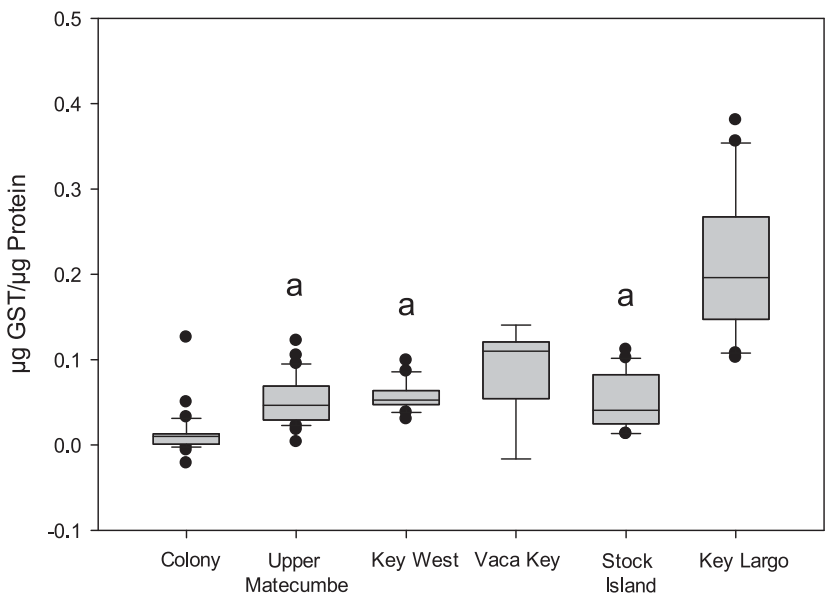

FIGURE 6. Box plots characterizing the 25th, 50th, and 75th percentiles of enzyme levels measured in male Aedes aegypti collected from ovitraps in Monroe County, FL, compared with susceptible colony. Outliers lie outside the 10th and 90 th percentiles as symbols. Identical letters denote no significant difference at $P<0.05$.

protein) were not significantly different from each other but were significantly higher than the colony (median $0.00102 \mu \mathrm{g}$ oxidase/ $\mu$ g protein) and Vaca Key (median $0.00042 \mu \mathrm{g}$ oxidase/ $\mathrm{gg}$ protein). Levels of GST were significantly higher for all

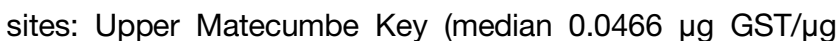

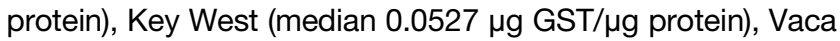

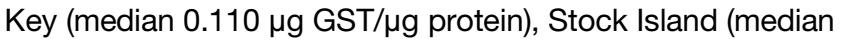
$0.0406 \mu \mathrm{g} \mathrm{GST} / \mu \mathrm{g}$ protein), and Key Largo (median $0.196 \mu \mathrm{g}$ 


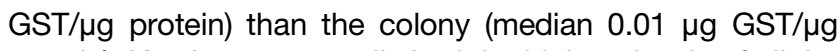
protein). Key Largo generally had the highest levels of all the enzymes tested with Upper Matecumbe Key, with Key West having the second highest and Vaca Key having the lowest levels. For ACE-1, only Stock Island (0.2045 frequency, 95\% Cl: 0.085$)$ and Vaca Key (0.111 frequency, 95\% Cl: 0.073) had individuals that were heterozygous for the mutation, whereas the population from Upper Matecumbe Key, Key Largo, and Key West were all homozygously susceptible.

A key form of pyrethroid resistance is target site insensitivity. Overexposure to pyrethroids may result in the reduction in binding capacity and the action potential of the sodium channel being modified. Insects that do not experience paralysis and maintain coordinated activity following pyrethroid exposure are considered to have knockdown resistance $(\mathrm{kdr}) .^{24}$ Frequencies for each of the possible $\mathrm{kdr}$ mutations tested listed are in Table 2. Molecular assays were run on mosquitoes from Upper Matecumbe Key, Stock Island, Key Largo, Key West, Vaca Key, Plantation Key, and survivors from the lethal ovitraps. No mutation at the Gly 1016 site was detected. The highest frequency among all populations was 0.711 (95\% Cl: 0.108) for Met 1011. The range for Met 1011 was 0.885 (95\% Cl: 0.340$)$ on Vaca Key to 0.231 (95\% Cl: $0.089)$ from survivors of the lethal ovitraps. The overall frequency of lle 1016 was 0.340 (95\% Cl: 0.050$)$ with a range of 0.214 (95\% Cl: 0.071) on Vaca Key to 0.425 (95\% Cl: 0.186$)$ on Key Largo. The overall frequency of Val 1011 was $0.372(95 \%$ $\mathrm{Cl}$ : 0.054) with a range of 0.283 (95\% Cl: 0.101) on Upper Matecumbe Key to 0.438 (95\% Cl: 0.214 ) on Plantation Key. In general, although the frequency of the mutations was high for Met 1011 across the Keys, the survivors from the lethal ovitraps had the lowest frequency of this mutation $(95 \% \mathrm{Cl}$ : $0.231,0.089$ ).

\section{DISCUSSION}

Aedes aegypti vector control is currently the main approach for controlling and preventing Aedes-borne arboviruses. Vector control strategies depend greatly on the application of chemical insecticides through ultralow volume or indoor space spraying to target adult mosquitoes and larviciding to target larvae. ${ }^{27}$ Reliance on insecticides has resulted in the development of resistance in Ae. aegypti to both classes of adulticides used in the continental United States (http:// www.pesticideresistance.org/). Insecticide resistance is becoming an increasing problem that can affect control efforts during a disease outbreak. Routine resistance testing and determination of the underlying resistance mechanisms are

TABLE 2

Frequencies of Ile 1016, Gly 1016, Val 1011, and Met 1011 alleles and genotypes associated with knockdown resistance in Aedes aegypti from the Florida Keys, Monroe County, FL

\begin{tabular}{|c|c|c|c|c|c|c|}
\hline Ile 1016 & Ile/lle (AA) & $\| \mathrm{le} / \mathrm{Val}(\mathrm{AG})$ & $\mathrm{Val} / \mathrm{Nal}(\mathrm{GG})$ & $N$ & Frequency AA & $95 \% \mathrm{Cl}$ \\
\hline Key Largo & 5 & 7 & 8 & 20 & 0.425 & 0.186 \\
\hline Key West & 5 & 11 & 14 & 30 & 0.325 & 0.125 \\
\hline Plantation Key & 0 & 9 & 7 & 16 & 0.281 & 0.138 \\
\hline Stock Island & 0 & 14 & 6 & 20 & 0.350 & 0.153 \\
\hline Upper Matecumbe & 0 & 23 & 5 & 28 & 0.411 & 0.152 \\
\hline Lethal ovitraps & 2 & 20 & 10 & 32 & 0.375 & 0.130 \\
\hline Vaca Key & 0 & 15 & 20 & 35 & 0.214 & 0.071 \\
\hline Overall frequency & 12 & 99 & 70 & 181 & 0.338 & 0.049 \\
\hline Gly 1016 & Gly/Gly (GG) & Gly/Nal (GT) & Val/Nal (TT) & $N$ & Frequency GG & $95 \% \mathrm{Cl}$ \\
\hline Key Largo & 0 & 0 & 20 & 20 & 0.000 & NA \\
\hline Key West & 0 & 0 & 30 & 30 & 0.000 & NA \\
\hline Plantation Key & 0 & 0 & 16 & 16 & 0.000 & NA \\
\hline Stock Island & 0 & 0 & 20 & 20 & 0.000 & NA \\
\hline Upper Matecumbe Key & 0 & 0 & 29 & 29 & 0.000 & NA \\
\hline Lethal ovitraps & 0 & 0 & 32 & 40 & 0.000 & NA \\
\hline Vaca Key & 0 & 0 & 35 & 35 & 0.000 & NA \\
\hline Overall frequency & 0 & 0 & 190 & 190 & 0.000 & NA \\
\hline Val 1011 & $\mathrm{Val} / \mathrm{Nal}(\mathrm{GG})$ & $\mathrm{Val} / \mathrm{lle}(\mathrm{GA})$ & Ile/lle (AA) & $N$ & Frequency GG & $95 \% \mathrm{Cl}$ \\
\hline Key Largo & 0 & 17 & 3 & 20 & 0.425 & $\overline{0.186}$ \\
\hline Key West & 0 & 23 & 7 & 30 & 0.383 & 0.137 \\
\hline Plantation Key & 0 & 14 & 2 & 16 & 0.438 & 0.214 \\
\hline Stock Island & 0 & 20 & 0 & 20 & 0.500 & 0.219 \\
\hline Upper Matecumbe Key & 0 & 17 & 13 & 30 & 0.283 & 0.101 \\
\hline Lethal ovitraps & 3 & 19 & 12 & 34 & 0.368 & 0.124 \\
\hline Vaca Key & 0 & 20 & 13 & 33 & 0.303 & 0.103 \\
\hline Overall frequency & 3 & 130 & 50 & 161 & 0.372 & 0.054 \\
\hline Met 1011 & Met/Met (GG) & Met/lle (GA) & Ile/lle (AA) & $N$ & Frequency GG & $95 \% \mathrm{Cl}$ \\
\hline Key Largo & 10 & 10 & 0 & 20 & 0.750 & 0.329 \\
\hline Key West & 17 & 13 & 0 & 30 & 0.783 & 0.280 \\
\hline Plantation Key & 9 & 5 & 2 & 16 & 0.719 & 0.352 \\
\hline Stock Island & 8 & 12 & 0 & 20 & 0.700 & 0.307 \\
\hline Upper Matecumbe Key & 23 & 7 & 0 & 30 & 0.883 & 0.316 \\
\hline Lethal ovitraps & 3 & 6 & 17 & 26 & 0.231 & 0.089 \\
\hline Vaca Key & 20 & 6 & 0 & 26 & 0.885 & 0.340 \\
\hline Overall frequency & 90 & 59 & 19 & 168 & 0.677 & 0.108 \\
\hline
\end{tabular}

$\mathrm{NA}=$ not applicable. Also provided are the sample sizes and $95 \%$ Cls around allele frequency estimates. 
essential in determining which insecticide is effective in controlling local mosquito populations.

In this study, we characterized the presence of resistance from multiple localities within Monroe County, FL. For each island that was sampled, Ae. aegypti had varying levels of resistance with different underlying mechanisms present. Bottle assays conducted at both Florida Keys Mosquito Control District and the CDC demonstrated resistance to type I pyrethroids. Even though the results of PHEREC bottle assays indicated phenotypic resistance to Biomist $30+30$ (Figure 2), the CDC bottle bioassays showed no phenotypic resistance to permethrin or malathion (Figure 3), but resistance was detected for bifenthrin (Figure 4). The profiles for enzyme expression in the populations differed from island to island despite the usage of the same chemicals throughout the entire county. This was also true for the presence of the kdr and ACE-1 target site mutations. Variability in resistant phenotypes and genotypes at a small geographical scale elucidates the focal and complex nature of insecticide resistance.

From 2005 to 2010, adulticides used in Monroe County, FL, contained either the active ingredient permethrin or naled. In 2011, treatment with malathion began in conjunction with permethrin and naled. In general, the cumulative number of $\mathrm{km}^{2}$ treated with permethrin across all islands was greatest in 2009 and for naled in 2005 and 2008. The largest cumulative number of $\mathrm{km}^{2}$ treated for permethrin, naled, and malathion occurred in Key Largo with 1142.1, 376.4, and $285.6 \mathrm{~km}^{2}$, respectively. Key Largo exhibited the highest expression of $\alpha$ and $\beta$ esterases, oxidases, GSTs, and frequency of the V1016l mutation from all islands tested. The least amount of area treated with permethrin occurred in Stock Island with $11.1 \mathrm{~km}^{2}$. For naled, no treatment occurred in Vaca Key for multiple years. Expression of $(\alpha)$ and $(\beta)$ esterases, oxidases, and acetylcholine esterase in mosquitoes from Vaca Key was not significantly different from that in mosquitoes from the susceptible colony even though the mosquitoes exhibited the highest levels of protein of all sites tested. The lowest treatment with malathion of $3.0 \mathrm{~km}^{2}$ occurred in Upper Matecumbe Key.

Male and female Ae. aegypti from Key West were assessed using the results from the biochemical assays. Males had significantly higher levels of $\beta$ esterase (median 0.469 ), oxidase (median 0.00141), GST (median 0.0473), and ACE-1 (median 0.00320) than females. Yet, the males were significantly smaller (median 85.436) when evaluated against the females (median 138.029). In a study by Arnaud and Haubruge, ${ }^{28}$ malathion-specific resistance in red flour beetle males, Tribolium castaneum (Herbst), led to higher rates of reproductive success than susceptible males. Resistant phenotype advantage may arise from enhanced male mating success, resistant males improved capacity in sperm competition, female mate choice, or cryptic female selection of resistance genes.

High levels of resistance were observed in populations tested at Florida Keys Mosquito Control District from Key West using the PHEREC assay for Biomist 30+30. However, no resistance was detected to permethrin using the CDC bottle bioassay on mosquitoes collected from Key West. In Figure 7, a comparison of the results from the two different bottle bioassays is shown. Permethrin is a racemic mixture of cis and trans isomers. The toxicity of permethrin is dependent on the ratio of the isomers present; the cis isomer being more

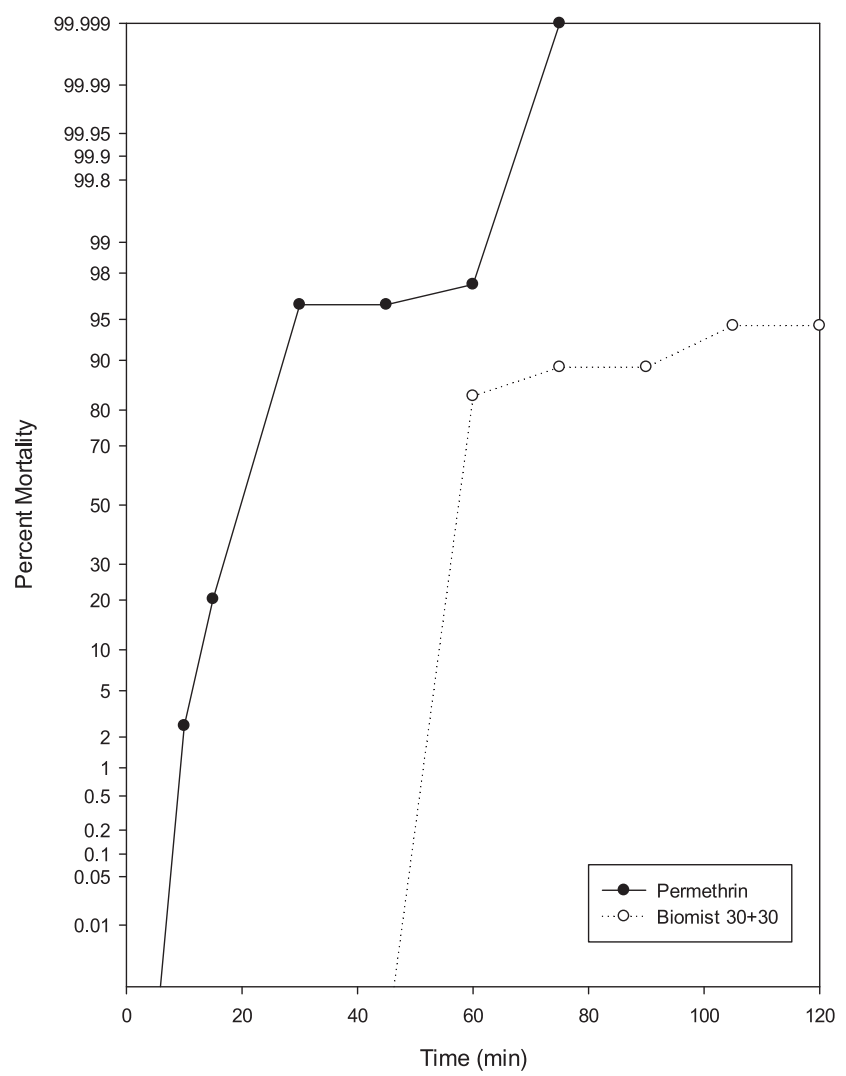

FIGURE 7 . Comparison of mortality curves of Aedes aegypti collected from Key West, FL, using permethrin in the CDC bottle bioassay and Biomist $30+30$ in the Public Health Entomology Research and Education Center bottle bioassay.

toxic. Technical-grade permethrin used in this study had a 25: 75 cis:trans isomer ratio, whereas Biomist $30+30$ had a 35:65 ratio. The formulated Biomist $30+30$ product not only contains permethrin but also $\mathrm{PBO}$ and inert ingredients that contribute to the effectiveness of the product and can be insecticidal. Differences in mortality between the formulated product and technical grade permethrin potentially arise from resistance to PBO or the inert ingredients. Piperonyl butoxide is not indicated to be toxic or highly toxic, but it is an active ingredient in insecticides and is in fact insecticidal. ${ }^{29}$ For more than 50 years, PBO has been used in combination with other insecticides, mainly synthetic pyrethroids, as a synergist. Piperonyl butoxide enhances a formulation by inhibiting nonspecific esterases and P450s, and increases cuticular penetration of the insecticide. ${ }^{30}$ Metabolic enzyme systems are at a normal level in susceptible insects, whereas elevated levels or altered systems are observed in resistant insects. In susceptible mosquitoes, the main active ingredient in a product is functioning at the greatest effect, and the use of $\mathrm{PBO}$ may generate little to no amplification. In resistant insects, PBO inhibits heightened metabolic enzyme systems resulting in the insect being more sensitive. ${ }^{31}$ However, Valles et al. ${ }^{32}$ reported that PBO antagonized toxicity of fipronil to one strain of German cockroaches (Blattella germanica [L.]). Other instances of antagonism of toxicity of insecticides by PBO have been reported. $^{33}$ No studies, thus far, have been conducted to examine resistance to PBO in insect populations. Inert ingredients may be chemically or biologically active and act as 
adjuvants which enhance or modify the capability of pesticide formulations to affect significant toxicologic endpoints. ${ }^{34}$ Ingredients present within a pesticide formulation are often regulated differently, with inert ingredients sometimes being unregulated despite their known toxicity. ${ }^{35}$ Manufacturers also do not generally identify inert ingredients on product labels as they consider the ingredients to be proprietary. Differences in mortality between bottle assays conducted at the Florida Keys Mosquito Control District and the CDC may also be the result of variances between collection date and location. The intensity of pesticide-centered vector control fluctuates both over time and in space. ${ }^{36}$ A study by Verhaeghen et al. ${ }^{37}$ reported that variances in the genetics and biology of vector populations in certain ecological locales might influence spatial and seasonal fluctuation in insecticide resistance. Variability in phenotypic and genotypic resistance can exist between blocks in the same community.

Adults reared from eggs collected from lethal ovitraps expressed significantly increased levels of $\beta$ esterase, oxidase, and GST but decreased levels of a esterase when compared with the susceptible colony. Interestingly, female mosquitoes from the lethal ovitraps were significantly smaller with a median of $101.5 \mu \mathrm{g} / \mathrm{mL}$ of protein than the median of $134.3 \mu \mathrm{g} / \mathrm{mL}$ for the susceptible colony. Resistance to bifenthrin was seen in the bottle bioassay, with $90.2 \%$ mortality at the threshold time. The use of inhibitors demonstrated that phenotypically esterases, oxidases, and GSTs were contributing to resistance as complete susceptibility was recovered at the threshold time. This correlates with the biochemical assays in which levels of all of these enzymes were overexpressed. It has been shown that larvae exposed to constant insecticides or pollutants have increases in tolerance to various insecticides and induction of multiple detoxification genes. The use of insecticides in agriculture represents an important selective force likely to affect all types of pyrethroid resistance mechanisms. ${ }^{38}$ In Benin, it was reported that Anopheles gambiae females frequently lay eggs in larval habitat sites located around agricultural settings. ${ }^{39}$ The authors suggested that larvae from these sites underwent selection pressure from agricultural pesticides, favoring the emergence of resistance. The presence of other agrochemicals, urban or industrial pollutants, and plant compounds in larval habitats is expected to affect pyrethroid tolerance by modulating mosquito detoxification systems. ${ }^{38}$ Gene expression analyses have implied that insecticide detoxification and possibly cuticular thickness are both amplified in mosquitoes emerging from polluted environments. ${ }^{40}$

Usually kdr limits the effectiveness of pyrethroids to varying degrees whether the insecticide contains a a-cyano-3phenoxybenzyl moiety (type II pyrethroid) or comprises a wide structural variety lacking the $\alpha$-cyano-3-phenoxybenzyl group (type I pyrethroid). ${ }^{24}$ Type II pyrethroids usually prolong the inactivation of the voltage-gated sodium channel significantly longer, and their effects are less reversible than type I. ${ }^{41}$ Farnham et al. ${ }^{42}$ found that the kdr factor confers a relatively consistent level of resistance throughout various pyrethroid structures and toxicities. This suggests that the mutation is not specifically sensitive to structural differences within the pyrethroid molecule. Geographic differences exist between the kdr mutations tested. The V1016I mutation is only found in the Americas, whereas the V1016G mutation is found in Asia. The overall frequency of the $\mathrm{V} 1016 \mathrm{I}$ and $\mathrm{M} 1011 \mathrm{I}$ mutations was $34.0 \%$ and $71.3 \%$, respectively. Saavedra-Rodriguez et al. ${ }^{23}$ found strong association of permethrin resistance to the Vssc locus containing the V1016I mutation and that individuals with the M1011I mutation did not appear to be associated with elevated pyrethroid resistance.

Estep et al. ${ }^{43}$ tested mosquitoes from one island from Monroe County, Big Coppitt Key. The use of topical bioassays showed Big Coppitt Key had 6-fold permethrin resistance when compared with the susceptible ORL1952 strain. Knockdown resistance genotyping for the V1016I mutation demonstrated a frequency of $11 \%$. Big Coppitt Key had the lowest levels of permethrin resistance and V1016I frequency compared with 26 sites tested in eight different counties throughout Florida in the study. Miami Beach in Miami-Dade County had the highest frequency level of $\mathrm{V} 1016 \mathrm{I}$ mutation of 91\%. Our findings showed that the V1016I frequency in Key Largo which is $70 \mathrm{~km}$ from Miami Beach was $42.5 \%$, the highest of all sites tested. Patterns and rate of gene flow between Ae. aegypti populations are shaped by mosquito migration through human transference of containers infiltrated with eggs or larvae and through the complex and dynamic spatiotemporal mosaic of insecticide pressure. ${ }^{44}$ Aedes aegypti populations within $150 \mathrm{~km}$ of one another experience high rates of gene flow with the spread of alleles at all loci, including resistance loci. Frequencies of resistance alleles increase where insecticides are used. Equally, resistance alleles within the population decrease in regions where insecticides are no longer used, assuming that a negative fitness cost is connected to the allele. Even with high widespread frequencies of pyrethroid resistance alleles and high gene flow, pyrethroid susceptibility can persist locally. ${ }^{45}$

Given the results of this study, the use of Biomist $30+30$ should be discontinued in Key West and Vaca Key for control of Ae. aegypti mosquitoes. The kdr mutation was found in mosquitoes tested from all sites which can impact the efficacy of all pyrethroids. Phenotypic resistance was not observed to malathion in mosquitoes from Key West. A pesticide formulation containing malathion as the active ingredient may be a more viable option for control operations. Formulations synergized with PBO might also be avoided until further testing can be conducted to determine the role of $\mathrm{PBO}$ in resistance. Phenotypic resistance data from bottle bioassays quantify the strength of resistance within a population and can elucidate the presence of detoxification mechanisms using inhibitors, but was limited by egg hatch rates in the laboratory. The CDC recommends that only technical-grade active ingredients be used when conducting the bottle bioassay as the adjuvant ingredients in formulated products are unknown, and synergists can disguise the presence of resistance. When resistance is detected, both molecular and biochemical analyses should be performed to elucidate specific enzymes responsible in resistance. Increased enzyme levels observed within the various sites tested are most likely not only contributing to resistance but also could have arisen to external environmental factors. Surveillance for resistance needs to be continuous not only in Monroe County, FL, but across the United States to detect alterations in susceptibility to the active ingredients used for operations, but also to identify effective ingredients if resistance is detected. Resistance monitoring is a vital component of any mosquito control program. During a disease outbreak, it is imperative to know whether the product being deployed is effectual in controlling the mosquito population. 
Received August 14, 2019. Accepted for publication July 21, 2020.

Published online January 11, 2021.

Acknowledgment: We would like to thank the USDA Center for Medical, Agricultural, and Veterinary Entomology in Gainesville, FL, for providing Aedes aegypti eggs from susceptible and resistant strains.

Financial support: Funding for this study was provided by the CDC and the Florida Keys Mosquito District.

Disclosure: The findings and conclusions in this article are those of the authors and do not necessarily represent the views of the CDC.

Authors' addresses: Mariah L. Scott and Janet C. McAllister, Arbovirus Diseases Branch, Division of Vector-Borne Diseases, Centers for Disease Control and Prevention, Fort Collins, CO, E-mails: gni6@ cdc.gov and jvm6@cdc.gov. Lawrence J. Hribar and Andrea L. Leal, Florida Keys Mosquito Control District, Key West, FL, E-mails: Ihribar@keysmosquito.org and aleal@keysmosquito.org.

This is an open-access article distributed under the terms of the Creative Commons Attribution (CC-BY) License, which permits unrestricted use, distribution, and reproduction in any medium, provided the original author and source are credited.

\section{REFERENCES}

1. Sawicki RM, 1987. Definition, detection and documentation of insecticide resistance. Combating Resistance to Xenobiotics: Biological and Chemical Approaches. Chichester, United Kingdom: Ellis Horwood.

2. Brogdon WG, McAllister JC, 1998. Insecticide resistance and vector control. Emerg Infect Dis 4: 605-613.

3. Bohart RM, Murray WD, 1950. DDT resistance in Aedes nigromaculis larvae. Proc Calif Mosq Control Assoc 18: 22-23.

4. Fox I, Boike AH, Garcia-Moll I, 1960. Notes on rock hole breeding and resistance of Aedes aegypti in Puerto Rico. Am J Trop Med Hyg 9: 425-429.

5. Burton GJ, 1964. Results of insecticide resistance tests against Aedes aegypti adults and larvae in British Guiana. Mosq News 24: 200-202.

6. Entwhistle PF, 1964. The Distribution of Mirid Species and of Resistant Mirids in Nigeria. Proceedings of the Conference on Mirid Pests of Cacao, West African Cacao Research Institute, Ibadan, Nigeria, 9-17.

7. Flynn AD, Schoof HF, Morlan HB, Porter JE, 1964. Susceptibility of 17 strains of Aedes aegypti (L.) from Puerto Rico and the Virgin Islands to DDT, dieldrin, and malathion. Mosq News 24: 118-123.

8. Klassen W, Brown AWA, 1964. Genetics of insecticide-resistance and several visible mutants in Aedes aegypti. Can J Genet Cytol 6: $61-73$.

9. Dick OB, San Martin JL, Montoya RH, Diego J, Zambrano B, Dayan $\mathrm{GH}, 2012$. Review: the history of dengue outbreaks in the Americas. Am J Trop Med Hyg 87: 584-593.

10. CDC, 2010. Locally acquired dengue-Key West, Florida, 2009-2010. MMWR Morb Mortal Wkly Rep 59: 577-581.

11. Rodrigues Faria N, Lourenço J, Marques de Cerqueira E, Maia de Lima M, Pybus O, Carlos Junior Alcantara L, 2016. Epidemiology of chikungunya virus in Bahia, Brazil, 2014-2015. PLoS Curr, doi: 10.1371/currents.outbreaks.c97507e3e48efb946401755d468c28b2.

12. Sahiner F, 2016. Global spread of Zika virus epidemic: current knowledges and uncertainties. Mikrobiyol Bul 50: 333-351.

13. Ranson H, Burhani J, Lumjuan N, Black WC, 2010. Insecticide resistance in dengue vectors. Trop/KA.net $J$ 1. Available at: http://journal.tropika.net/scielo.php?script=sci_arttext\&pid= S2078-86062010000100003\&lng=en.

14. Petersen J, 2003. Dilution of Biomist 30+30 ULV for the Bottle Bioassay. Public Health Entomol Res Education Center Technical Memorandum No. 7. Florida Mosquito Control Handbook, Panama City, FL.

15. Brogdon WG, McAllister JC, 1998. Simplification of adult mosquito bioassays through use of time-mortality determinations in glass bottles. J Am Mosq Control Assoc 14: 159-164.

16. Brogdon WG, Dickinson CM, 1983. A microassay system for measuring esterase activity and protein concentration in small samples and in high-pressure liquid chromatography eluate fractions. Anal Biochem 131: 499-503.

17. Brogdon WG, 1987. Microassay of acetylcholinesterase activity in small portions of single mosquito homogenates. Comp Biochem Physiol C 90: 145-150.

18. Brogdon WG, Barber AM, 1990. Microplate assay of glutathione S-transferase activity for resistance detection in singlemosquito triturates. Comp Biochem Physiol B 96: 339-342.

19. Brogdon WG, McAllister JC, Vulule J, 1997. Heme peroxidase activity measured in single mosquitoes identifies individuals expressing an elevated oxidase for insecticide resistance. J Am Mosq Control Assoc 13: 233-237.

20. McAllister JC, Godsey MS, Scott ML, 2012. Pyrethroid resistance in Aedes aegypti and Aedes albopictus from Port-Au-Prince, Haiti. J Vector Ecol 37: 325-332.

21. Vulule JM, Beach RF, Atieli FK, McAllister JC, Brogdon WG, Roberts JM, Mwangi RW, Hawley WA, 1999. Elevated oxidase and esterase levels associated with permethrin tolerance in Anopheles gambiae from Kenyan villages using permethrinimpregnated nets. Med Vet Entomol 13: 239-244.

22. Bradford MM, 1976. A rapid and sensitive method for the quantitation of microgram quantities of protein utilizing the principle of protein-dye binding. Anal Biochem 72: 248-254.

23. Saavedra-Rodriguez K et al., 2007. A mutation in the voltage-gated sodium channel gene associated with pyrethroid resistance in Latin American Aedes aegypti. Insect Mol Biol 16: 785-798.

24. Garcia GP et al., 2009. Recent rapid rise of a permethrin knock down resistance allele in Aedes aegypti in Mexico. PLoS Negl Trop Dis 3: e531.

25. WHO, 2013. Test Procedures for Insecticide Resistance Monitoring in Malaria Vector Mosquitoes. Geneva, Switzerland: World Health Organization.

26. Scott ML, McAllister J, 2012. Comparison of biochemical and molecular tests for detecting insecticide resistance due to insensitive acetylcholinesterase in Culex quinquefasciatus. J Am Mosq Control Assoc 24: 323-326.

27. Morrison AC, Zielinski-Gutierrez E, Scott TW, Rosenberg R, 2008. Defining challenges and proposing solutions for control of the virus vector Aedes aegypti. PLoS Med 5: e68.

28. Arnaud L, Haubruge E, 2002. Insecticide resistance enhances male reproductive success in a beetle. Int J Org Evol 56: 2435-2444.

29. Dove WE, 1947. Piperonyl butoxide, a new and safe insecticide for the household and field. Am J Trop Med Hyg 27: 339-345.

30. Bingham G, Strode C, Tran L, Khoa PT, Jamet HP, 2011. Can piperonyl butoxide enhance the efficacy of pyrethroids against pyrethroid-resistant Aedes aegypti? Trop Med Int Health 16: 492-500.

31. Moores GD, Philippou D, Borzatta V, Trincia P, Jewess $P$, Gunning R, Bingham G, 2009. An analogue of piperonyl butoxide facilitates the characterization of metabolic resistance. Pest Manag Sci 65: 150-154.

32. Valles SM, Koehler PG, Brenner RJ, 1997. Antagonism of fipronil toxicity by piperonyl butoxide and S, S, S-tributyl phosphorotrithioate in the German cockroach (Dictyoptera: Blattellidae). J Econ Entomol 90: 1254-1258.

33. Haley TJ, 1978. Piperonyl butoxide, a[2-(2-butoxyethoxy)ethoxy]4,5-methylenedioxy-2-propyltoluene: a review of the literature. Ecotoxicol Environ Saf 2: 9-31.

34. Cox C, Surgan M, 2006. Unidentified inert ingredients in pesticides: implications for human and environmental health. Environ Health Perspect 114: 1803-1806.

35. Mesnage R, Antoniou MN, 2018. Ignoring adjuvant toxicity falsifies the safety profile of commercial pesticides. Front Public Health 5: 361.

36. Saavedra-Rodriguez $\mathrm{K}$ et al., 2015. Local evolution of pyrethroid resistance offsets gene flow among Aedes aegypti collections in Yucatan state, Mexico. Am J Trop Med Hyg 92: 201-209.

37. Verhaeghen K, Bortel WV, Roelants P, Okello PE, Talisuna A, Coosemans M, 2010. Spatio-temporal patterns in kdr frequency in permethrin and DDT resistant Anopheles gambiae s.s. from Uganda. Am J Trop Med Hyg 82: 566-573.

38. Nkya TE, Akhouayri I, Kisinza W, David J-P, 2013. Impact of environment on mosquito response to pyrethroid insecticides: facts, evidences and prospects. Insect Biochem Mol Biol 43: 407-416. 
39. Akogbeto MC, Djouaka RF, Kinde-Gazard DA, 2006. Screening of pesticide residues in soil and water samples from agricultural settings. Malar J 5: 22.

40. Djouaka R, Bakare A, Coulibaly O, Akogbeto M, Ranson H, Hemingway J, Strode C, 2008. Expression of the cytochrome P450s, CYP6P3, and CYP6M2 are significantly elevated in multiple pyrethroid resistant populations of Anopheles gambiae s.s. from southern Benin and Nigeria. BMC Genomics 9: 538.

41. O'Reilly AO, Khambay BPS, Williamson MS, Field IM, Wallace BA, Davies TGE, 2006. Modelling insecticide-binding sites in the voltage-gated sodium channel. Biochem J 396: 255-263.
42. Farnham AW, Murray AWA, Sawicki RM, Denholm I, White JC, 1987. Characterization of the structure-activity relationship of $\mathrm{kdr}$ and two variants of super-kdr to pyrethroids in the housefly (Musca domestica). Pestic Sci 19: 209-220.

43. Estep AS et al., 2018. Quantification of permethrin resistance in kdr alleles in Florida strains of Aedes aegypti (L.) and Aedes albopictus (Skuse). PLoS Negl Trop Dis 12: e0006544.

44. Marini G, Guzzetta G, Rosa R, Merler S, 2017. First outbreak of Zika virus in the continental United States: a modelling analysis. Euro Surveill 22: 301-312.

45. Flores AE, Reyes-Solis GDC, Salas IF, Ponce G, 2009. Resistance to permethrin in Aedes aegypti (L.) in northern Mexico. Southwest Entomol 34: 167-175. 